UDC 379.845(045)

Kiril D. Nikolaev, post-graduate, student

\title{
ENVIRONMENTALLY SOUND TOURISTIC POTENTIAL OF REGIONS OF UKRAINE
}

The general concepts and provisions of ecological tourism are given in the article, natural-recreational potential of Ukraine, a problem and prospect of development national ecotourism, its role in ecological-safe of development are considered.

Розглянуто загальні поняття й положення про екологічний туризм, природно-рекреаційний потенціал України, проблеми й перспективи розвитку національного екотуризму, його роль в еколого-безпечному розвитку.

\section{Introduction}

One of the ways to overcome critical condition of human soul is cognitive exploration of national treasures, in particular - historical, cultural and natural treasury.

Nowadays ecological tourism in its all versions from living on manor of the hospitable huzul (with cold and hot water, satellite TV, etc.) to visiting wild woods or unique geological monuments hidden among mountains become more and more popular in Ukraine, and especially in protected areas.

However only people of healthy moral and high intelligence are capable to feel the true pleasure from dialogue with nature and the sacral historical environment [1].

The word "tourism" translated from French means "walk", "trip".

In the today's world tourism is also rather profitable area of business.

The World tourist organization estimated, this industry gave a profit of more than 1,5 billion in 2006.

Ecological tourism became separate direction within this powerful branch of industry during the last few years, and experts all over the world recognize it as one of the most perspective kinds of tourism. Ecological tourism is now the main source of incomes for Kenya, Costa Rica and other countries. By different estimations ecological tourism makes $10-20 \%$ of all world tourism market and it is area which develops dynamically. United Nations Organization (UNO) declared 2002 year "Year of ecological tourism". Ecological tourism is completely not necessary difficult trip with a very heavy backpack.

Ecotourism can be comfortable enough, but thus its organizers and participants understand, that supercomfort for any price, especially among the innocent nature is impossible. And, on the contrary, the tourist in fragmentary jeans can appear rather far from principles of ecotourism. Unfortunately, such tourists in the majority of the cut fur-tree branches, young trees for tents leave fire and garbage in the place which was pleasant, and, in general, thoughtlessly and ruthlessly use the nature.

Mass amateur and sport tourism which was so strongly developed in our country, frequently causes significant damage to sensitive ecosystems.

Depending on the basic purpose it can be divided into: studying wildlife or cultivated nature in order to receive basic ecological knowledge; rest in the natural surroundings to get emotional, aesthetic pleasure; health treatment with natural factors; sports and adventures and others.

According to the main object of the tour, which defines its content and partially the form of its organization, ecotours can be classified into [2]:

- botanical;

- zoological;

- geological;

- ecothnographical;

- archeologic;

- ecocultural;

- agricultural-rounds or rural green rounds;

- speleological, hydrological;

- mountain tours and others.

\section{Raising of problem}

Ecological tourism is directed on the guard of natural and cultural environment of regions which are visited by tourists.

Ecological tourism with his enormous recreational possibilities is called to form public consciousness in relation to a guard and rational use of natural resources.

Therefore, it is necessary to define possibilities of introduction ecological tourism and explore touristic and recreational potential of Ukraine.

\section{Analysis of researches and publication}

Problems, prospects of development of ecological tourism and methods of his introduction, are examined in works of V. Hetman, S. Komarchuk, O. Kryganovska, O. Kuzmenko and others. They determine importance of development of ecological tourism on territory of our state, and also economic, social ana cultural prospects from this industry. 


\section{Aims}

On today of all greater popularity in Ukraine acquires ecological tourism exactly. It is important to define basic directions and terms of his development on territory of Ukraine. And also, to be determined with the system of modern management and management by recreational activity in different regions.

\section{Terms for development}

Natural-recreational resources are natural conditions, landscapes, natural phenomena which create comfortable conditions for touristic activity and contribute to the organization of rest and recreation. The most important among them are climate, water, landscapes with vegetation and fauna, and also some natural objects which have cognitive, aesthetic and other properties. Climatic resources determine the general comfort of territory, its suitability for treatment and rest.

A climate on the majority of territory of Ukraine is moderately continental, with dry and mainly warm summer and mild winter. The daily average temperature exceeds $+10{ }^{0} \mathrm{C}$ approximatly 150-190 days a year. Climatic conditions in the Carpathian and the Crimean Mountains, and also on the southern coast of the Crimea are different. Very important component of recreational resources is water resources, which includes seas, lakes, water basins, rivers, suitable for organization of rest and recreation. The most important are the Sea of Azov and the Black Sea, and also the greatest rivers of Ukraine - the Dnieper, the Dniester, the Southern Bug, the Donets, the Danube and thousands of smaller rivers which run through the territory of Ukraine. The main waterway of Ukraine - the Dnieper River, the third longest river of Europe (2285 km, within the limits of Ukraine - $1205 \mathrm{~km}$ ).

The Carpathian rivers are suitable for fascinating travel on kayaks and canoes (the Cheremosh, the Prut, the Tisa, the Striey, etc.).

Over 3 thousand natural lakes and 22 thousand artificial water bodies are on the territory of Ukraine. The greatest amount of lakes is on the Volynsk Polissya, among which the famous lake Svitjaz is (depth up to $60 \mathrm{~m}$, karstic origin, rich of fish, including such exotic - as eel).

The important part of natural recreational resources is presented with balneological - mineral waters, medical dirts. Recreational establishments, which function due to the use of balneological resources, are located mainly in the Carpathians and on the Black Sea Coast.
The greatest amount of mineral sources is concentrated within the Western Ukraine (the Lviv and Transcarpathian areas).

Significant stocks of medical dirts are concentrated in the southern and the northwest areas.

The oldest dirt resorts are Berdyansk, Evpatoria, Saki, Kualnik.

The peat dirts are used on the resorts of Mirgorod, Morshin, Cherche, etc.

The important component of recreation and treatment is wood resources.

Ukraine occupies one of the first places by the area of wood plantings among the countries of Europe.

Presence of woods also assists to the development of specific kinds of tourism, in particular - hunting, for elks, deer, wild bears, foxes, feathery game of the Carpathian region, Polissya and the Black Sea Coast. Landscapes with recreational or cognitive properties have significant value for tourism. There are caves in Ukraine as big and beautiful as the most famous known in the world, and having appropriate equipment, it is possible to transform them into the recreational and tourism objects of the international value (Podolia, Bukovina, Crimea and Carpathian region).

The Total area of natural recreational landscapes in Ukraine is 9,4 million hectares $(15,6 \%$ of its territory) with simultaneous capacity of 5 million people.

Special group of interesting unique landscapes is formed of national parks, reserves and other unique natural objects, monuments of nature, parksmonuments of landscape gardening art, dendroparks, botanical gardens, zoological parks, reserved natural boundaries which comprise rich and various nature reserved fund of Ukraine. However, some part of these unique recreational resources are under special protection, and has limited access for tourists. However it is very valuable and perspective part and as a result it requires correction of the restrictions, calculations of permissible anthropogenic pressure, development of new rules and regulations etc [3].

Historical and cultural resources include historical, archeologic, architectural monuments, subjects of material culture (instrument of work, household things, products of national crafts, clothes, national kitchen), elements of spiritual culture (fine arts, folklore, national traditions, belief and etc.), products of monumental art, ethnographic features of territory.

This group of resources also includes museums, exhibitions, theatres and etc. 
This kind of resources is also extremely rich and various in Ukraine.

Over 15.6 thousand monuments of town-planning and architecture are under protection of the state, and this is not full list of valuable historical and architecture objects.

The chronological range of the cultural monuments of Ukraine is also very wide.

The rests of the most ancient of them belong to the period of Ancient Greece and are located on the Northern Black Sea Coast (Olvia, Chersonese, Panticapaeum, etc.).

The following by age objects are the first stone constructions of Ancient Rus which belong to X-XIIIth centuries, presented with cult objects:

- St. Spaskiy Cathedral in Chernigov;

- St. Sophia Cathedral and Golden Gates in Kyiv;

- St. Spasa Church in Berestov;

- St. Uspenskiy Cathedral and St. Troitska Nadbrama Church in Kyiv-Pechersky Lavra;

- ensemble of Pochaivska Lavra;

- St. Mikhail Cathedral in Vydubetsky Monastry;

- St. Kyryll Church in Kiev;

- St. Yuriy Church in Kaniv;

- St. Vasyl Church in Ovruch;

- St. Borysoglibskiy Cathedral;

- St. Illia Church, Uspenskiy Cathedral of Eletskiy

Monastery and St. Piatnytsa Church in Chernigov;

- Uspenskiy Cathedral in Volodymyr-Volynsk;

- Church of St. Panteleymon in Ivano-Frankovsk areas.

During XIV-XVIIth centuries in the western regions the special attention was concentrated on construction of defensive objects - stone fortresses, monasteries, churches-fortresses. there are nearly 150 monuments of defensive architecture, which are located in 46 cities, 23 small towns, 45 villages in the Western Ukraine and are under protection of the state.

But unfortunatly the majority of these constructions are destroyed and abandoned. In the XVIIth century the special architectural style of Ukrainian baroque, which dominated during XVIIIth century, appeared. Reorganizations of old buildings according to this style were done: St. Sophia and Uspenskiy Cathedral in Kyiv and St. Uspenskiy Cathedral in Chernigov. Ensembles of Kyiv-Pechersky Lavra, Sophia Monastery and the historical center of Lvov are included to the list of the world heritage of UNESCO.

The historical ensembles of Kyiv, KamainetsPodolsk, Novgorod-Siversk and Chernigov etc. are perspective candidates to this list.
In Ukraine 1399 cities and settlements and about 8 thousand villages have valuable historical heritage, among of them - 39 historical cities which have age of more thousand years. The most outstanding historical architectural ensembles and complexes, generally forty seven, which proclaimed to be national parks, among them - Ancient Galich, KyivPechersky Lavra, T.G.Shevchenko's Grave, St. Sophia Cathedral in Kyiv, Chersonese, Hortitsa have the status national parks.

The total number of natural monuments in Ukraine is 6 thousand and number of historical and cultural monuments is 150 thousand. Of this number 12 thousand have an interest as touristical-excursion objects, but in such role function only about 5,5 thousand (according to some sources 8 thousand). In Ukraine there are also 550 museums in which over 9,9 million exhibits are kept [4].

Homogeneous resources, which are natural and cultural-historical complexes connected with the past of Ukraine, and other states play an important role in touristic and excursion activity as which understand the. They include places, connected with life and activity of outstanding representatives of other states on territory of Ukraine (O.Balzaka, A.Mitskevicha, A.Rishele, F.Lista, U.Cherchelja, J.Gasheka, etc.), places of fights and burials (the military memorial, devoted to British killed during the Crimean war of 1853-1855, burials of Swedes on the battle-field at Poltava, etc.). According to the calculations of O.O.Bejdik calculations, there are over 500 objects of this kind in different regions of Ukraine. The biggest part of them is presented in the Western Ukraine (Lviv, Transcarpathia, Chernivtsy), Odessa areas, Crimea and in Kyiv. Over $80 \%$ of these resources have not been involved in the organization of tours for foreigners yet [5].

Infrastructural resources have now crucial importance for effective development of tourism. They are components of a social and industrial infrastructure, which can be used in the organization of tourism, and cover the infrastructure of a territory and all the enterprises involved in reception and service of tourists: excursion and transport service, hotel and auxiliary (bank, financial, communications, life, trading, entertaining, etc.) services.

Among them transport and venue are the most important.

In Ukraine today there are 1375 enterprises of hotel type among which 920 hotels, 20 motels, 9 campings, etc. 
But unfortunately only about $10 \%$ of this amount corresponds to the international standards and are suitable for service of foreign tourists.

Only in 2001 the first five-star hotel appeared in Ukraine though the network of four-stars hotels have already counted many objects in Kyiv, Yalta, Odessa,Lvov and Chernovtsy.

As a whole touristical-recreational and sanitaryresort complex of Ukraine includes over 4,5 thousand enterprises of tourists accommodation, which can simultaneously accept over 600 thousand people, but, certainly, the majority of them requires improvement, modernization, enhancement to the European standards [6].

According to natural and socio-economic factors and needs of tourist area territory of Ukraine is divided into tourist regions and areas. The tourist region is a territory touristic system of some tourist areas which have specific features and are united by geographical, historical and resource factors. In turn, the tourist area is a group of tourist complexes incorporated by common territorial structure of tourist facilities.

The basis of tourist division into districts is defining separate units which differ by tourist specialization, structure of recreational resources and direction of their development.

The uniform plan of tourist and recreational division into districts of Ukraine has not been developed yet. it is possible to accept the plan of recreational division into districts from the Geographical encyclopedia of Ukraine as a basis: the territory of the country is divided in 4 recreational regions (Azov-Chornomorsk, Dniprovsk-Dnistrovsk, Carpathian, Crimean) or 8 recreational areas (Evpatorija, Donetsk, Odessa, Pryazov, Prydniprovsk, Prydnistrovsk, Feodosija, Yalta) [7].

The Azov-Chornomorsk recreational region which consists of Donetsk, Zaporozhye, Nikolaev, Odessa, Kherson areas, includes Odessa and Pryazovsk recreational areas (with rich resources of medical dirts).

Dniprovsko-Dnestrovskiy recreational region (Vinnitsa, Volynsk, Zhitomir, Dnepropetrovsk, Donetsk, Kyiv, Kirovograd, Lugansk, Poltava, Sumy, Ternopol, Kharkov, Khmelnitskiy, Cherkassk, Chernovtsy, Chernigov areas) covers Donetsk, Prydniprovskiy and Pridnestrovsky areas. The region becomes famous for mineral and radonic waters.
Carpathians recreational region includes Transcarpathia, Ivano-Frankivsk, Lviv, Chernovtsy areas. About 800 sources of mineral water are revealed here and half is in Transcarpathia.

The region has the thickest river network in the country - 8729 rivers. A lot of historical and cultural monuments are here. It is located on the crossroads of ways which connect the Western and the Eastern Europe.

The Crimean recreational region is a unique cell which unites rich natural-recreational, historical, cultural and sports resources.

Among them - the Black and Azov Seas, medical dirts, thermal and mineral waters of balneological resorts, numerous monuments, which belong to different epochs and cultures and are created by different people.

Classification and estimation of tourist resources of Ukraine, mode of their protection, the use in view of calculation of maximum permissible loadings, the order of preservation of integrity and reproduction of tourist resources of Ukraine, actions for their development are determined according to the legislation of Ukraine and belong to one of the major duties of the state.

\section{Conclusion}

The tourist area gets greater importance as it contributes to the development of economy and social sphere in Ukraine, it is promptly integrated into the world tourist industry.

The priority direction of development of external and internal tourism is an important factor of improvement of life standard in Ukraine, formation of additional workplaces, updating foreign currency reserves of the state and increase of its authority on international scene.

Development of tourism in Ukraine influences work of other 40 areas of economy, and especially transport, communication, construction, an agriculture, manufacture of the consumer goods, and is one of the most perspective directions of structural reorganization of economy. In turn, the important factor of development of tourism is naturalrecreational condition and historical and cultural potential of the country, which was specified above. The system of modern management and management of recreational activity in regions also does not meet the requirements.

Domination of the departmental approach to development of is natural-resource potential caused absence of necessary regulatory base for 
management of regional economic complex, there are no adequate statistical data and techniques of estimation of economic benefit, brought to adjacent branches of industry, there are no corresponding positions in the index of industrial branches.

There isn't efficient organizational vertical of management which unites subjects of different ownership and departmental subordination.

Regulatory authorities doesn't use modern administrative technologies (geoinformation and expert systems, bases and databanks), that does not allow to organize efficient accounting of managed objects, to create cadastres of natural medical resources and natural territories of resorts.

The level of scientific and methodical maintenance of bodies of regional management does not allow to make scientifically sound decisions (both strategic, and tactical plan), that leads to inefficient use of financial assets.

Contemporary conditions worsen by metasystem factors - difficult social and economic situation in Ukraine which develops on the background of decrease of control and low efficiency of social production, further deterioration of ecological condition of habitats and health of the population. The main reason of such situation is extremely insufficient level of financing from the state and republican programs of development, protection and rational use of natural resources, and also developments of engineering infrastructure of touristic and recreational areas.
The most difficult problem to solve for the development of tourism in Ukraine, is, indoubtedly, improvements of transport network and improvement of service quality to the international standards, and also creation of positive image of Ukraine as tourist state, and promotion of national tourist product to the internal and external, international service market. Meanwhile, these aspects of tourist activity are the most important [8].

\section{References}

1. Бейдик О.О. Рекреаційно-туристські ресурси України: методологія та методика аналізу, термінологія, районування: монографія. - К.: ВПЦ “Київський університет”, 2001. - 395 с.

2. Гетьман B.I. Екотуризм: теорія і реальність // Рідна природа. -2002. - № 3. - С. 24-29.

3. Дмитрук О.Ю. Урбанізація та еотуризм: теорія і практика конструктивно-географічних досліджень. К.: Київський інститут ім. Т.Г. Шевченка, 2002. - 76 с. 4. Комарчук C. Заповідний фонд України: стан, проблеми, перспективи розвитку // Рідна природа. 2003. - № 1. - С. 78-80.

5. Маєвський Я. Агротуризм: порадник для сільського господаря. - Л., 2005. - 80 с.

6. Крижановська О. Установи природно-заповідного фонду як осередки екологічної освіти та виховання // Рідна природа. - 2003. - № 1. - С. 14-16.

7. Кузьменко $O$. Екологічний туризм: поняття i особливості організації // Схід. - 2004. - № 2. - С. 13-17.

8. Гетьман B.I. Курортно-рекреаційні системи Українських Карпат // Український географічний журнал. - 1999. - № 3. - С. 34-37.

The editors received the article on 15 April 2008. 